\title{
DNA Polymerase Inhibitor
}

National Cancer Institute

\section{Source}

National Cancer Institute. DNA Polymerase Inhibitor. NCI Thesaurus. Code C29575.

Any substance that inhibits DNA polymerase, an enzyme that catalyzes the addition of deoxyribonucleotide residues to the end of a DNA molecule. Inhibition of DNA polymerase causes an inhibition of DNA synthesis and results in cell cycle arrest. 